\title{
Genetic and phenotypic diversity of Rhizobium isolates from Southern Ecuador
}

\section{Diversidade genética e fenotípica de isolados de Rhizobium do sul do Equador}

\author{
Roldán Torres-Gutiérrez ${ }^{1 *}$, Klever Iván Granda-Mora², Yelenys Alvarado-Capó ${ }^{3}$, \\ Aminael Sánchez Rodriguez, Noroska Gabriela Salazar Mogollón'1, José Rafael de Almeida1
}

\author{
${ }^{1}$ Universidad Regional Amazónica/IKIAM, Tena-Napo, Ecuador \\ ¿Universidad Nacional de Loja, Centro de Biotecnología, Loja, Ecuador \\ ¿Universidad Central "Marta Abreu" de Las Villas, Instituto de Biotecnología de las Plantas, Villa Clara, Cuba \\ ${ }^{4}$ Universidad Técnica Particular de Loja, Departamento de Ciencias Naturales, Loja, Ecuador \\ ${ }^{*}$ Corresponding author: roldan.torres@ikiam.edu.ec \\ Received in March 26, 2017 and approved in September 6, 2017
}

\begin{abstract}
Rhizobium-legume symbioses play relevant roles in agriculture but have not been well studied in Ecuador. The aim of this study was to characterize the genetic and phenotypic diversity of Rhizobium isolates associated with Phaseolus vulgaris from southern Ecuador. Morphocultural characterization, biochemical tests and physiological analyses were conducted to authenticate and determine the diversity of bacteria Rhizobium-like isolates. The genetic diversity of the isolates was determined by molecular techniques, which consisted of bacteria DNA extraction and amplification and sequencing of the $16 \mathrm{~S}$ rRNA gene. The nodulation parameters and nitrogen fixation for $P$. vulgaris under greenhouse conditions were also assessed to determine the phenotypic diversity among isolates. Furthermore, bacteria indole-acetic-acid production was evaluated by the colorimetric method. Morpho-cultural and biochemical characteristic assessments demonstrated that Rhizobium-like bacteria was associated with the $P$. vulgaris nodules. The diversity among the isolates, as determined by physiological analyses, revealed the potential of several isolates to grow at different $\mathrm{pH}$ values, salinity conditions and temperatures. Partial sequencing of the $16 \mathrm{~S}$ rRNA gene identified the Rhizobium genus in every sampling site. From a total of 20 aligned sequences, nine species of Rhizobium were identified. Nodule formation and biomass, as well as nitrogen fixation, showed an increase in plant phenotypic parameters, which could be influenced by IAA production, especially for the strains $R$. mesoamericanum NAM1 and R. leguminosarum bv. viciae COL6. These results demonstrated the efficiency of native symbiotic diazotrophic strains inoculants for legume production. This work can serve as the basis for additional studies of native Rhizobium strains and to help spread the use of biofertilizers in Ecuadorian fields.
\end{abstract}

Index terms: Phaseolus vulgaris; diazotrophic bacteria; 16S rRNA gene; nodulation; indole acetic acid.

\section{RESUMO}

A simbiose Rhizobium-leguminosa desempenha um relevante papel na agricultura, entretanto não tem recebido suficiente atenção de estudos científicos no Equador. O objetivo deste artigo foi caracterizar a diversidade genética e fenotípica de isolados de Rhizobium associados com Phaseolus vulgaris do sul do Equador. A caracterização morfo-cultural, testes bioquímicos e análises fisiológicas foram realizados para autenticar e determinar a diversidade de isolados de bactérias Rhizobium. A diversidade genética foi determinada por por técnicas moleculares consistindo na extração de DNA genômico bacteriano, amplificação e sequenciamento parcial do gene 16SrRNA; e parâmetros de nodulação e fixação de nitrogênio de $P$. vulgaris sobre condições de estufa foram testados para determinar a diversidade fenotípica entre os isolados. Além disso, a produção de ácido indolacético foi avaliada por um método colorimétrico. A análise fisiológica da diversidade entre os isolados revelou o potencial de crescimento de diversos isolados em diferentes níveis de $\mathrm{pH}$, salinidade e temperatura. O sequenciamento parcial do gene 16S rRNA mostrou o gênero Rhizobium em todas os locais de amostragem. De um total de 20 sequências alinhadas, 9 espécies de Rhizobium foram identificadas. A formação de nódulos e biomassa, bem como a fixação de nitrogênio mostraram um aumento nos parâmetros fenotípicos das plantas, os quais devem ser influenciados pela produção de IAA, especialmente pelas cepas $R$. mesoamericanum NAM1 e R. leguminosarum bv. viciae COL6. Estes resultados demonstram a eficiência de cepas diazotróficas simbióticas nativas para produção de inoculantes para leguminosas e fornece informações valiosas e uteis para a agricultura sustentável equatoriana. Neste sentido, este trabalho deve ser um elemento essencial para a realização de futuras pesquisas aplicadas relacionadas a cepas Rhizobium nativas e espalhar o uso de biofertizantes em campos equatorianos.

Termos para indexação: Phaseolus vulgaris; bactéria diazotrófica; 16S rRNA gene; nodulação; ácido indolacético.

\section{INTRODUCTION}

The common bean (Phaseolus vulgaris L.) is the most important grain legume worldwide and plays a significant role in human nutrition, being a major source of dietary protein and representing a rich source of minerals and vitamins (Zaccardelli; Pentagelo; Tripodi, 2013). As a 
legume, beans can carry out biological nitrogen fixation (BNF) through symbiosis with root nodule-associated soil bacteria collectively called rhizobia, which contribute to plant nutrition and allow plants to grow in nitrogen deficient soils (López-Guerrero et al., 2012; Sánchez et al., 2014).

The amount of nitrogen fixed by the common bean in association with rhizobia under field conditions is often low compared to that of other legumes (Remans et al., 2008a). The success of the symbiotic process depends on the competitiveness, specificity, compatibility, and effectiveness of the rhizobia with its host legume under variable soil and environmental conditions (Naveed et al., 2015). One of the major reasons for the low response of this grain legume that it is a highly promiscuous host (Fuentes et al., 2002; Baginsky et al., 2015). The presence of rhizobia, which are comprised of different genera and species in the same host nodule, may be a result of genetic diversification and adaptation of the bacteria to their environment. However, the efficiency of nodulation and nitrogen fixation could be influenced by the infection of several rhizobia in the same host (Wei et al., 2008; Ormeño-Orilla; Martínez-Romero, 2013).

P. vulgaris nodule rhizobia have been extensively investigated (Kaschuk et al., 2006; Rahmani et al., 2011; Zhang et al., 2014), and it has been shown that, at its sites of origin, there are preferred symbionts, but in introduced areas it is promiscuous and may function as a less functional host plant (Michiels et al., 1998), forming nodules with diverse indigenous bacteria (MartínezRomero, 2003). In Ecuador, an Andean region from which common bean originates (Rodiño et al., 2010), few rhizobia identification studies have been conducted, despite potentially being an important source of rhizobial diversity, which is a key determinant of common bean productivity (Baginsky et al., 2015). Recently, Ribeiro et al. (2015) determined the taxonomic affiliations of isolated strains from Ecuadorian soil previously reported by Bernal and Graham (2001) and Mexican strains, showing that all the Ecuadorian isolates corresponded to three novel lineages from the Rhizobium etli group that fall into the $R$. phaseoli/R. etli/R. leguminosarum clade. One of these lineages, with representatives isolated mostly from Ecuador, seems to be a dominant lineage associated with beans from that northern and central region (Ribeiro et al., 2013). This was one of the first studies in this Andean region, and additional research must be conducted to increase our understanding of the distribution patterns of rhizobial species in Ecuador.

Although a great deal of knowledge has been amassed concerning the diversity and genetics of common bean symbionts, the basis of a successful inoculation and efficient nitrogen fixation remain elusive (Martínez-Romero, 2003). The few previous studies from the Ecuadorian Andean region have focused only on determining the phylogenetic potential of symbionts (Bernal; Graham, 2001; Ribeiro et al., 2013). However, the effect of rhizobia on plant phenotypic parameters and the variability among isolated strains are rarely studied under laboratory, greenhouse or field conditions. Therefore, it is important to assess the phenotypic parameters of isolated strains, such as tolerance to $\mathrm{pH}$, temperature and salinity (Marquina; González; Castro, 2011), the stimulatory effect of indole-3-acetic acid (Remans et al., 2008b), as well as nodule formation and biomass production when they are inoculated in the host plant (Wei et al., 2008; Mehboob et al., 2013). The determination of these parameters is not only necessary to elucidate the capability of isolated strains to grow under different environmental conditions but also to understand how bacterial inoculation enhances plant growth and yields.

The aim of this study was to characterize the genetic and phenotypic diversity of Rhizobium isolates associated with Phaseolus vulgaris from southern Ecuador. The ability of isolated strains to stimulate plant growth was assessed to evaluate the diversity and phenotypic variation of Rhizobium isolates from the southern region of Ecuador, taking into account molecular analysis (16S rRNA gene), cultural parameters, indole acetic acid-produced by bacteria and the effect of isolates on nodulation and biomass in the common bean in a greenhouse assay. Encouraging results will help change agricultural practices and revitalize the worldwide interest in BNF, particularly in low input systems (Naveed et al., 2015).

\section{MATERIAL AND METHODS}

\section{Sampling}

Sampling was performed in nine municipalities of Loja province in the southern region of Ecuador. In each of the sampling areas, roots of Phaseolus vulgaris plants with nodules were taken randomly and stored in moisturized Ziploc ${ }^{\circledR}$ bags to prevent drying. Global positioning system data were recorded at each collection point and altitudinal levels (meters over sea level, m.o.s.l.) were determined. Table 1 shows the sampling sites, geolocation position, altitudinal levels and soil types at each sampling site. 
Table 1: Sampling sites, altitudinal levels and geolocation.

\begin{tabular}{|c|c|c|c|c|c|c|}
\hline \multirow{2}{*}{ Municipality } & \multirow{2}{*}{ Samples } & \multicolumn{3}{|c|}{ Geolocation } & \multirow{2}{*}{ Soil type } & \multirow{2}{*}{ Altitudinal levels** } \\
\hline & & $\mathrm{S}$ & W & Height* (m.o.s.l) & & \\
\hline Pindal & 4 & $04^{\circ} 07^{\prime} 06^{\prime \prime}$ & $80^{\circ} 06^{\prime} 32^{\prime \prime}$ & 800 & Inceptisols & \multirow{2}{*}{1} \\
\hline Paltas & 3 & $04^{\circ} 02^{\prime} 46^{\prime \prime}$ & $79^{\circ} 46^{\prime} 78^{\prime \prime}$ & 940 & Entisols & \\
\hline Catamayo & 4 & $04^{\circ} 05^{\prime} 99^{\prime \prime}$ & $79^{\circ} 18^{\prime} 29^{\prime \prime}$ & 1078 & Inceptisols & \multirow{5}{*}{2} \\
\hline Calvas & 2 & $04^{\circ} 26^{\prime} 56^{\prime \prime}$ & $79^{\circ} 35^{\prime} 52^{\prime \prime}$ & 1193 & Inceptisols & \\
\hline Sosoranga & 3 & $04^{\circ} 19^{\prime} 50^{\prime \prime}$ & $79^{\circ} 47^{\prime} 35^{\prime \prime}$ & 1549 & Entisols & \\
\hline Gonzanamá & 3 & $04^{\circ} 07^{\prime} 87^{\prime \prime}$ & $79^{\circ} 25^{\prime} 50^{\prime \prime}$ & 1680 & Inceptisols & \\
\hline Loja & 8 & $03^{\circ} 56^{\prime} 86^{\prime \prime}$ & $79^{\circ} 12^{\prime} 48^{\prime \prime}$ & 2120 & Entisols & \\
\hline Celica & 2 & $04^{\circ} 05^{\prime} 95^{\prime \prime}$ & $79^{\circ} 57^{\prime} 78^{\prime \prime}$ & 2029 & Inceptisols & \multirow[t]{2}{*}{3} \\
\hline Saraguro & 5 & $03^{\circ} 36^{\prime} 56^{\prime \prime}$ & $79^{\circ} 15^{\prime} 26^{\prime \prime}$ & 2691 & Inceptisols & \\
\hline
\end{tabular}

${ }^{*}$ Average height of the sampling sites in meters over sea level (m.o.s.l.).

${ }^{* *}$ Altitudinal level 1: from 800 to 940 m.o.s.l.; altitudinal level 2: from 1078 to 1680 m.o.s.l.; altitudinal level 3: from 2120 to 2691 m.o.s.l.

\section{Sample preparation and bacterial isolation}

The isolation methodology proposed by Sánchez et al. (2014) was used with minimal modification. Briefly, individual nodules were dissected from the roots using a flame sterilized scalpel and tweezers and were washed thoroughly in distilled water using a sieve to remove all traces of soil. Subsequently, nodules were transferred to a sterile Petri dish and surface disinfected by immersion in $10 \mathrm{ml}$ of $3 \% \mathrm{NaClO}$ for 3 minutes, followed by immersion in $0.1 \% \mathrm{HgCl}_{2}$ for $2-5$ minutes. Finally, the nodules were washed profusely with sterile distilled water.

The surface-disinfected root nodules were crushed with the flattened end of a flamed glass rod in a sterile plate containing $1 \mathrm{ml}$ of sterile Milli-Q water. Afterwards, the bacterial suspension was streaked on solid YMA medium (Vincent, 1970) and the plates were incubated at $28{ }^{\circ} \mathrm{C}$ for \pm 7 days. Single colonies were purified by repeatedly streaking on YMA plates. After 2 days of purification, single colonies were individually analyzed by Gramstaining, morpho-cultural (growth rate, color, elevation, edges and slime production), and biochemical (growth in YMA+Congo Red, MacConkey and Kligler medium; catalase production; and production of acid or base) characterization (Somasegaran; Hoben, 1994). Cultural analyses were performed by testing growth at different $\mathrm{pH}$ values $(4,5$, and 9$), \mathrm{NaCl}$ concentrations $(0.1,1$ and $2 \%)$ and temperature $\left(10,35,40^{\circ} \mathrm{C}\right)$ in YMA medium at $30^{\circ} \mathrm{C}$ (Bécquer; Prévost; Prieto, 2000; Kulkarni; Nautiyal, 2000). For $\mathrm{pH}$ assays, the YMA medium was adjusted to the desired $\mathrm{pH}$ with $\mathrm{HCl}$ or $\mathrm{NaOH}$ before sterilization with an autoclave. All pure cultures were maintained on YMA and preserved at $4{ }^{\circ} \mathrm{C}$ for temporary storage or cryopreserved at $-80{ }^{\circ} \mathrm{C}$ with $50 \%(\mathrm{v} / \mathrm{v})$ glycerol for long-term storage.

\section{DNA extraction}

Isolated colonies were grown overnight in Yeast Extract-Mannitol (YM) medium at $30^{\circ} \mathrm{C}$ with shaking at $250 \mathrm{rpm}$ in a shaker incubator (Techine TS1500, USA). DNA extraction was performed using a ChargeSwitch ${ }^{\circledR}$ gDNA Mini Bacteria Kit (Invitrogen ${ }^{\mathrm{TM}}$, USA), according to the manufacturer's instructions. DNA quality was checked by quantification in Nanodrop (Nanodrop 2000, Thermo Scientific, USA) and electrophoresis in a $1 \%$ agarose gel (1 g agarose in $100 \mathrm{ml}$ TBE buffer).

\section{S rRNA gene amplification, purification and sequencing}

The $16 \mathrm{~S}$ rRNA gene of isolates was amplified with the conserved primers: ARI C/T (5'CTGGCTCAGGAC/TGAACGCTG3') and $\mathrm{pH}$ (5'AAGGAGGTGATCCAGCCGCA3') (Clermont et al., 2009), which amplify almost the full length of the $16 \mathrm{~S}$ rRNA gene (1500 bp). Each $50 \mu \mathrm{l}$ amplification reaction contained: $5 \mu \mathrm{ldNTPs}$ ( $2 \mathrm{mM}$ of each), $5 \mu \mathrm{l}$ GeneAmp 10X-PCR buffer (100 mMTris-HCl (pH 8.3)), $500 \mathrm{mM}$ $\mathrm{KCl}, 15 \mathrm{mM} \mathrm{MgCl}_{2}, 0.01 \%$ (w/v) gelatin), $0.5 \mu \mathrm{l}$ of each

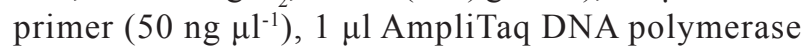

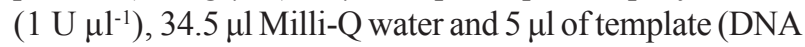
extracted from isolated colonies).

The following temperature cycling program was used: $5 \mathrm{~min}$ at $95^{\circ} \mathrm{C}$ to denature DNA, three amplification 
cycles $\left(45 \mathrm{sec}\right.$ at $94^{\circ} \mathrm{C}, 2 \mathrm{~min}$ at $55^{\circ} \mathrm{C}$, and $1 \mathrm{~min}$ at $\left.72^{\circ} \mathrm{C}\right), 30$ amplification cycles $\left(20 \mathrm{sec}\right.$ at $94^{\circ} \mathrm{C}, 1 \mathrm{~min}$ at $55^{\circ} \mathrm{C}$, and $1 \mathrm{~min}$ at $72{ }^{\circ} \mathrm{C}$ ) and $5 \mathrm{~min}$ at $72{ }^{\circ} \mathrm{C}$ for a final primer extension. All PCR products were analyzed by electrophoresis in a $1 \%$ agarose gel ( $1 \mathrm{~g}$ agarose in $100 \mathrm{ml}$ TAE buffer $)$ at 80 $\mathrm{V}$ for 45 minutes.

The PCR-amplified 16S rDNA fragments were purified using a PureLink ${ }^{\circledR}$ PCR Purification Kit (Invitrogen ${ }^{\mathrm{TM}}$, USA) according to the manufacturer's instructions and evaluated afterwards by electrophoresis in a $1 \%$ agarose gel.

Table 2 shows the primers used for each sequencing reaction (Clermont et al., 2009). For each sequencing reaction, a mixture was made of $1 \mu \mathrm{l}$ of purified PCR product, $0.5 \mu$ of the Big Dye ${ }^{\mathrm{TM}}$ Termination Ready Reaction Mix (Applied Biosystems), $3.75 \mu 1$ sterile Milli-Q water and $3 \mu \mathrm{l}\left(20 \mathrm{ng} \mu \mathrm{l}^{-1}\right)$ of one of the eight sequencing primers used.

The sequence analysis was performed using an Applied Biosystems 3100 DNA Sequencer following the manufacturer's protocols (Perkin-Elmer). Sequence assembly was performed with BioNumerics version 4.5 (Applied Maths, Sint-Martens-Latem, Belgium). The closest related sequences were identified using the FASTA program (Pearson, 1990). Sequences were also compared with those available in the GenBank database.

\section{Greenhouse assay}

All isolates were assessed to determine their capability to promote nodule number, biomass production and $\mathrm{N}$ content of $P$. vulgaris in pot experiments under greenhouse conditions. This work is a more detailed study of the Rhizobium-common bean (Mantequilla) interaction, which was published previously (Granda-Mora et al., 2016). For the experiment, a complete randomized experimental design with ten replicates was performed. The inoculation with the wild-type strain Rhizobium etli
CNPAF512 (obtained from the culture collection of the Centre for Microorganism and Plant Genetic of Catholic University of Leuven, Belgium) and a treatment without inoculation were the controls.

Certified $P$. vulgaris cv. Mantequilla seeds were obtained at Loja Market. The pots contained a substrate that was a mixture of soil, sand and organic matter $(2: 1: 1)$ sterilized at $120^{\circ} \mathrm{C}$ for 2 hours. Seeds were surface disinfected as described previously by Vlassak et al. (1998) and pre-germinated for two days on moist filter paper in the dark at $28{ }^{\circ} \mathrm{C}$. One pre-germinated seedling was planted per pot.

The inocula preparation consisted of pure bacteria cultures grown overnight in liquid medium (YM) at $30^{\circ} \mathrm{C}$ with shaking at $250 \mathrm{rpm}$ in an incubated shaker (Techine TS1500, USA). The inocula were prepared as reported by Remans et al. (2007). Cells were washed twice with $10 \mathrm{mM} \mathrm{MgSO}_{4}$ and resuspended in $10 \mathrm{mM} \mathrm{MgSO}_{4}$ at a density of $10^{7}$ colony forming units (CFU) $\mathrm{ml}^{-1}$. Finally, common bean seedlings were inoculated with $0.2 \mathrm{ml}$ of an inoculum containing $10^{7} \mathrm{CFU}$.

A complete randomized experimental design was performed with ten pots as replicates for every treatment. Plants were grown under greenhouse conditions to control moisture, pests and weeds during the entire assay.

Plants were harvested at 21 days after inoculation (DAI) to determine nodule number, nodule dry weight ( $\mathrm{mg}$ ) and total nitrogen content in the shoots ( $\%$ total $\mathrm{N})$ according to the Kjeldahl method (Page; Miller; Keeney, 1982).

\section{Quantification of indole acetic acid (IAA) production by isolates}

IAA quantification was carried out by a colorimetric method using Salkowski reagent, consisting of $4.5 \mathrm{~g} \mathrm{FeCl}_{3}$ per liter in $10.8 \mathrm{M} \mathrm{H}_{2} \mathrm{SO}_{4}$ (Glickmann; Dessaux, 1995) in the supernatant of cultures.

Table 2: Primers used for sequencing reaction.

\begin{tabular}{cccc}
\hline Name & Direction & Primer sequence & Amplification region \\
\hline Gamma & Forward & 5'CTCCTACGGGAGGCAGCAGT3' & $339-358$ \\
& Reverse & 5'ACTGCTGCCTCCCGTAGGAG3' & $358-339$ \\
$*$ PD & Forward & 5'CAGCAGCCGCGGTAATAC3' & $519-536$ \\
& Reverse & 5'GTATTACCGCGGCTGCTG3' & $536-519$ \\
$* 0$ & Forward & 5'AACTCAAAGGAATTGACGG3' & $908-926$ \\
& Reverse & 5'GTTGCGCTCGTTGCGGGACT3 & $1112-1093$ \\
& Forward & 5'AGTCCCGCAACGAGCGCAAC3' & $1093-1112$ \\
& Reverse & 5'GCTACACACGTGCTACAATG3' & $1241-1222$ \\
\hline
\end{tabular}


A previous experiment that was done to test the ability of strains to produce IAA without any IAA precursor in the media did not generate a result after measuring the optical density (OD) in a spectrophotometer. Therefore, all strains, including the wild-type strain as a positive control, were grown overnight in YM media with the addition of L-tryptophan (Sigma, $2.5 \mathrm{mg} \mathrm{ml}^{-1}$ ) and were incubated in a shaker (Techine TS1500, USA) at $30^{\circ} \mathrm{C}, 250$ rpm. From each culture, $1 \mathrm{ml}$ was transferred to a sterile Eppendorf tube and centrifuged for $5 \mathrm{~min}$ at $6000 \mathrm{rpm}$. For the reaction, the supernatant was transferred to a fresh Eppendorf tube and $1 \mathrm{ml}$ of the supernatant was added to $1 \mathrm{ml}$ of Salkowski reagent and left in the dark for $30 \mathrm{~min}$ at room temperature. From the mixed solution, $1 \mathrm{ml}$ was transferred to a micro-cuvette and the absorbance was measured at $530 \mathrm{~nm}$ (Jen Way $6505 \mathrm{UV} / \mathrm{VIS}$, UK). The IAA concentration at the exponential phase of growth was estimated using a standard curve. For this purpose, a serial dilution of IAA (Sigma; 5, 10, 20, 50 and $100 \mu \mathrm{g} \mathrm{ml}^{-1}$ ) was made and incubated with Salkowski reagent using the same procedure described previously. The (OD) absorbance was measured at a wavelength of $530 \mathrm{~nm}$ and a standard curve was obtained by plotting the ODs against the concentrations. Three replicates were taken for statistical analysis and curve standardization.

\section{Statistical analysis}

Data from each assay were tested for normality and homogeneity of variances for each variable and then assessed by analysis of variance (ANOVA), using a significance level of $p<0.05$. SPSS Statistics 21.0 for Windows (IBM) was used and the means for each treatment were compared using Tukey's HSD as a post hoc significance test.

\section{RESULTS AND DISCUSSION}

It is generally accepted that $P$. vulgaris is native to the Americas. The analysis of natural bean populations has led to the proposal of two major centers of diversification: the Mesoamerican center (Mexico, Central America and Colombia) and the Andean center (Ecuador, Peru and Bolivia) (Beebe et al., 2001; Junier et al., 2014). However, the genetic diversity of rhizobianodulating beans in Ecuador is, for the most part, unknown (Ribeiro et al., 2015). In previous studies, Bernal and Graham (2001) and Ribeiro et al. (2013) reported on the diazotrophic rhizobial communities in soils of northern and central Ecuador. Recently, a new species, Rhizobium ecuadorense sp. nov., which was obtained from a common bean nodule, has been described as a lineage from Ecuador (Ribeiro et al., 2015). This suggests that Ecuador is the center of genetic diversification for the common bean (Debouck et al., 1993), and symbionts of the several species of Rhizobium should be isolated from this region (Ribeiro et al., 2013).

The first results of this work, involving the isolation of bacteria from bean nodules, identified 34 isolates, from which 20 corresponded to Rhizobium-like bacterial strains (found at all sampling sites), taking into account their morphological and biochemical characterization. All 20 isolates were fast growers, short Gram-negative rods, produced bacterial colonies that ranged from white to opaque color, ere elevated with regular edges and produced slime (Kuykendall; Family, 2005). The biochemical analysis showed that all strains grew on YMA+Congo Red with colonies ranging from pink to transparent in color. Furthermore, none of the strains fermented glucose in MacConkey medium, fermented neither lactose nor glucose and was a hydrogen sulfide producer in Kligler medium, and tested catalase positive and were acid producers, reinforcing that the isolated strains were Rhizobium (Somasegaran; Hoben, 1994).

The cultural analysis showed the diversity in the ability isolates to grow at different $\mathrm{pH}$ values, $\mathrm{NaCl}$ concentrations and temperatures (Table 3). These assessments are crucial to determine the ability of isolates to grow under different environmental stress conditions. Table 3 shows that most of the strains $(70 \%)$ were able to grow at an alkaline $\mathrm{pH}(9)$, while at $\mathrm{pH} 4$ only four strains (25\%) grew. From them, isolates SOS1 and SOS4 grew moderately well and CB1, LP1 and COL6 strains exhibited only slight growth. The isolates VP2, Z3 and PIN1 did not grow at any of the $\mathrm{pH}$ values. The rest of the isolates $(85 \%)$ were able to grow at $\mathrm{pH} 5$. Finally, only five isolates (COL6, CB1, LP1, SOS1 and SOS4) were capable of growing at the three $\mathrm{pH}$ values tested.

The assessment of growth at different $\mathrm{NaCl}$ concentrations showed that nine isolates $(45 \%)$ grew in $0.01 \% \mathrm{NaCl}$, five isolates $(25 \%)$ grew in $1 \% \mathrm{NaCl}$ and three isolates (15\%) grew in $2 \% \mathrm{NaCl}$. A total of 11 isolates (55\%) were susceptible at the three $\mathrm{NaCl}$ concentrations assessed, while only three isolates (COL6, CB1 and SOS1) were able to grow in all $\mathrm{NaCl}$ conditions.

Eight isolates $(40 \%)$ were characterized as psychrophiles, growing at $10{ }^{\circ} \mathrm{C}$, all the isolates $(100 \%)$ were able to grow at $28^{\circ} \mathrm{C}$, and 15 grew at $35^{\circ} \mathrm{C}(75 \%)$. of the latter group, eight exhibited slight growth, four exhibited moderate growth and three exhibited abundant growth. At $40{ }^{\circ} \mathrm{C}$, eight isolates $(40 \%)$ exhibited slight growth. 
Table 3: Cultural characteristics of isolates by sampling sites and altitudinal levels.

\begin{tabular}{|c|c|c|c|c|c|c|c|c|c|c|c|}
\hline \multirow{2}{*}{ Strain codes } & \multirow{2}{*}{ Sampled municipality } & \multicolumn{3}{|c|}{$\mathrm{pH}$} & \multicolumn{3}{|c|}{$\mathrm{NaCl}(\%)$} & \multicolumn{4}{|c|}{ Temperature $\left({ }^{\circ} \mathrm{C}\right)$} \\
\hline & & 4 & 5 & 9 & 0.01 & 1 & 2 & 10 & 28 & 35 & 40 \\
\hline NAR1 & Paltas & - & ++ & + & + & - & - & + & + & - & + \\
\hline PIN1 & Pindal & - & - & - & - & - & - & - & + & - & - \\
\hline PIN3 & Pindal & - & + & - & + & - & - & - & + & + & - \\
\hline TAB1 & Calvas & - & + & + & - & - & - & + & ++ & ++ & + \\
\hline COL1 & Calvas & - & + & - & - & - & - & - & + & + & - \\
\hline COL6 & Calvas & + & ++ & ++ & + & ++ & ++ & + & +++ & +++ & + \\
\hline TAM1 & Catamayo & - & + & + & - & - & - & - & + & + & - \\
\hline CB1 & Catamayo & + & + & + & + & + & + & + & + & + & + \\
\hline NAM1 & Gonzanamá & - & + & + & - & - & - & - & + & - & - \\
\hline sos1 & Sosoranga & ++ & ++ & ++ & ++ & ++ & + & + & + & + & + \\
\hline sos4 & Sosoranga & ++ & ++ & ++ & ++ & + & - & - & +++ & +++ & - \\
\hline LP1 & Célica & + & + & + & + & + & - & + & + & - & + \\
\hline VP1 & Loja & - & + & + & - & - & - & - & ++ & ++ & - \\
\hline VP2 & Loja & - & - & - & - & - & - & - & ++ & ++ & - \\
\hline $\mathrm{RC2}$ & Loja & - & ++ & + & - & - & - & - & + & - & - \\
\hline TUR1 & Loja & - & + & + & + & - & - & + & + & + & + \\
\hline RAl1 & Loja & - & + & + & - & - & - & - & ++ & ++ & - \\
\hline Q2 & Saraguro & - & ++ & + & + & - & - & - & +++ & +++ & - \\
\hline $\mathrm{Z1}$ & Saraguro & - & + & - & - & - & - & - & + & + & - \\
\hline $\mathrm{Z3}$ & Saraguro & - & - & - & - & - & - & + & + & + & + \\
\hline
\end{tabular}

Legend: - Non growth, + slight growth, ++ moderated growth, +++ abundant growth.

By comparing the cultural parameters of isolates with the average of altitudinal level by sampling site, it was evident that the strains isolated at level 2 (from 1078 to 1680 m.o.s.l.) were the most adapted to growth at different $\mathrm{pH}$ values, $\mathrm{NaCl}$ concentrations and temperatures. The strains CB1 (from Catamayo, 1078 m.o.s.l.), COL6 (from Calvas, 1193 m.o.s.l.) and SOS1 (from Sosoranga, 1549 m.o.s.l.) grew under all the conditions tested.

More than $90 \%$ of arable land has some type of stress, which causes more than $50 \%$ of crop losses worldwide (Yamal et al., 2016). For example, fluctuations in $\mathrm{pH}$, nutrient availability, temperature, and salinity, among other environmental stress factors, greatly influences the growth, survival, and metabolic activity of soil microorganisms and plants and their ability to enter into symbiotic interactions. In most cases, the microsymbiont is the more affected partner (Miransari et al., 2013). Therefore, the selection of stress-tolerant strains of Rhizobium are important under stressful environmental conditions (Zahran, 1999). In the present study, the physiological characterization showed a high tolerance of the strains COL6, CB1 and SOS1 to grow at different $\mathrm{pH}$ values, salinity conditions and temperatures. Similar results reported by Andrade, Murphy and Giller (2002) and Shamseldin and Werner (2005) suggest that strains of Rhizobium can tolerate acidic $\mathrm{pH}$ values and high concentrations of $\mathrm{NaCl}$. Thus, these native strains constitute a sustainable alternative to use as biofertilizer in sites with problems of environmental stress.

The 16S rDNA assay demonstrated the presence of nine species of Rhizobium, including: Rhizobium tropici, R. etli, R. etli bv. mimosae, R. leguminosarum, $R$. leguminosarum bv. viciae, $R$. mesoamericanum, $R$. undicola and two unclassified species, Rhizobium sp. and uncultured Rhizobium sp., supporting the idea that there is a wide diversity of species of this genera in Ecuador, 
as well as the predominant $R$. tropici, which nodulates P. vulgaris in southern Ecuador (Table 4). Although few studies have reported on the genetic diversity of Rhizobium in Ecuador (Ribeiro et al., 2013), this is the first report of species diversity in the southern region of the country. Similar to this study, $R$. etli, $R$. leguminosarum and $R$. tropici have been previously isolated from common bean nodules (Martínez-Romero, 2003; Aguilar; Riva; Peltzer,
2004; Oliveira et al., 2011) and are considered to be the predominant occupant species of bean nodules in the Andean region (Junier et al., 2014; Ribeiro et al., 2015).

Ecuador, north of Peru, Colombia and the Andean Region are currently considered to be the centers of domestication/diversity of the common bean (Oliveira et al., 2011). Thus, it is important to isolate native strains from this region to determine their ability to fix nitrogen,

Table 4: Genetic diversity of Rhizobium isolates by altitudinal levels.

\begin{tabular}{|c|c|c|c|c|c|}
\hline Strain Code & $\begin{array}{c}\text { Sampled } \\
\text { municipality }\end{array}$ & $\begin{array}{l}\text { Altitudinal } \\
\text { levels* }\end{array}$ & Accession $\mathrm{N}^{\circ}$ & Closest FASTA hit & $\begin{array}{l}\text { \% Sequence } \\
\text { identity }\end{array}$ \\
\hline NAR1 & Paltas & 1 & KP027690.1 & Rhizobium tropici str. MMUST-006 & 100 \\
\hline PIN1 & Pindal & 1 & JQ797311.1 & Rhizobium etli str. ECRI 15 & 100 \\
\hline PIN3 & Pindal & 1 & KP027691.1 & $\begin{array}{c}\text { Rhizobium leguminosarum bv. } \\
\text { viciae str. } \\
\text { MMUST-003 }\end{array}$ & 100 \\
\hline TAB1 & Calvas & 2 & EF555479.1 & Rhizobium sp. rf033 & 98 \\
\hline COL1 & Calvas & 2 & KP027691.1 & $\begin{array}{l}\text { Rhizobium leguminosarum bv. } \\
\text { viciae str. MMUST-003 }\end{array}$ & 100 \\
\hline COL6 & Calvas & 2 & KP027691.1 & $\begin{array}{l}\text { Rhizobium leguminosarum bv. } \\
\text { viciae str. MMUST-003 }\end{array}$ & 100 \\
\hline TAM1 & Catamayo & 2 & KP027690.1 & Rhizobium tropici str. MMUST-006 & 100 \\
\hline CB1 & Catamayo & 2 & KP027690.1 & Rhizobium tropici str. MMUST-006 & 100 \\
\hline NAM1 & Gonzanamá & 2 & JX122134.1 & Rhizobium mesoamericanum str. & 100 \\
\hline SOS1 & Sosoranga & 2 & KM672515.1 & Rhizobium undicola str. MR68 & 100 \\
\hline sos4 & Sosoranga & 2 & KC172298.1 & $\begin{array}{l}\text { Rhizobium uncultured. clone DM6- } \\
85\end{array}$ & 100 \\
\hline LP1 & Célica & 3 & KP027690.1 & Rhizobium tropici str. MMUST-006 & 100 \\
\hline VP1 & Loja & 3 & СР006986.1 & $\begin{array}{l}\text { Rhizobium etli bv. mimosae str. } \\
\text { IE4771 }\end{array}$ & 99 \\
\hline VP2 & Loja & 3 & KP027690.1 & Rhizobium tropici str. MMUST-006 & 100 \\
\hline $\mathrm{RC2}$ & Loja & 3 & KP027690.1 & Rhizobium tropici str. MMUST-006 & 100 \\
\hline TUR1 & Loja & 3 & KP027679.1 & $\begin{array}{l}\text { Rhizobium leguminosarum str. } \\
\text { KSM-004 }\end{array}$ & 100 \\
\hline RAl1 & Loja & 3 & KP027690.1 & Rhizobium tropici str. MMUST-006 & 100 \\
\hline Q2 & Saraguro & 3 & KP027691.1 & $\begin{array}{l}\text { Rhizobium leguminosarum bv. } \\
\text { viciae str. MMUST-003 }\end{array}$ & 100 \\
\hline $\mathrm{Z1}$ & Saraguro & 3 & KP027691.1 & $\begin{array}{l}\text { Rhizobium leguminosarum bv. } \\
\text { viciae str. MMUST-003 }\end{array}$ & 100 \\
\hline $\mathrm{Z3}$ & Saraguro & 3 & KP027691.1 & $\begin{array}{l}\text { Rhizobium leguminosarum bv. } \\
\text { viciae str. MMUST-003 }\end{array}$ & 100 \\
\hline
\end{tabular}

*Altitudinal level 1: from 800 to 940 m.o.s.l.; altitudinal level 2: from 1078 to 1680 m.o.s.l.; altitudinal level 3: from 20120 to 2691 m.o.s.l. 
and stimulate bean plants to obtain inoculants that provide benefits to farmers. The genetic diversity of the strains was remarkable at the three altitudinal levels. However, with respect to the cultural characterization, altitudinal level 2 (1078 to 1680 m.o.s.1.) was had the most variation in Rhizobium isolates, with the presence of six species: $R$. tropici, $R$. leguminosarum bv. viciae, $R$. mesoamericanum, R. undicola, Rhizobium sp. and an uncultured Rhizobium sp. These results reinforce the promiscuity of Phaseolus vulgaris to nodulate with several Rhizobium species, including Ecuadorian cultivars. A total of $35 \%$ of the strains under study were positioned in the $R$. tropici clade, which was dominant in the region regardless the sampling site or altitudinal levels. For altitudinal level 1, one strain was identified as R. tropici, while for altitudinal level 2 , two strains matched this species and at altitudinal level three, four strains belonged to this species.

Effective nodulation is essential for a functioning legume/Rhizobium symbiosis. In a previous study, we demonstrated that plants most susceptible to infection and capable of producing effective nodules should have greater potential to fix more atmospheric nitrogen (Sánchez et al., 2014). At 21 days after inoculation, all isolates were able to nodulate the host plant in the pot experiment under greenhouse conditions. The nodule number and nodule biomass were variable among the isolates (Figure 1), but most of them yielded significantly higher values than the controls, primarily for nodule number, highlighting the potential of native strains to nodulate a local beans cultivar.

In panel $\mathrm{A}$, the inoculation with $R$. leguminosarum bv. viciae COL6, $R$. etli bv. mimosae VP1 and Rhizobium mesoamericanum NAM1, were statistically significant among the treatments. However, no significant difference was observed among them and with $R$. tropici (NAR1), R. undicola (SOS1), $R$. tropici (LP1), R. tropici (VP2), $R$. leguminosarum bv. viciae (Q2) and $R$. leguminosarum bv. viciae (Z1). These nine bacterial isolates belonged to the group with the best nodule formation in bean plants (group A) forming an average of 75 nodules per plant. Following this group, a total of ten isolates (R. etli PIN1, R. leguminosarum PIN3, R. sp. TAB1, $R$. leguminosarum bv. viciae COL1, $R$. tropici TAM1, R. tropici CB1, $R$. uncultured SOS4, R. tropici $\mathrm{RC} 2, R$. tropici $\mathrm{RAI} 1$ and $R$. leguminosarum bv. viciae Z3) were clustered in the second most important group (B) for nodulation, and only one isolate (R. leguminosarum TUR1) and surprisingly wild type strain CNPAF512 were included in group $\mathrm{C}$, having the lowest nodule number. As expected, the control treatment was unable to nodulate the host plant.

In panel B, the nodular biomass showed significant differences among the isolates. A group A, with a total of seven isolates (R. tropici $\mathrm{RC} 2$, Rhizobium mesoamericanum NAM1, $R$. tropici LP1, R. leguminosarum bv. viciae Z1, $R$. sp. TAB1, $R$. leguminosarum PIN3 and $R$. leguminosarum bv. viciae COL6) exhibited the most significant results, with nodule dry weight values ranging from 70 to 92 $\mathrm{mg}$. The largest group (group B) of strains (11 isolates) had moderate nodule dry weights, with values from 38 to $65 \mathrm{mg}$, and the low values (group C) belonged to $R$. uncultured SOS4, R. leguminosarum TUR 1 and the wildtype strain CNPAF512. The results for these two strains were consistent with the nodule number.

The results obtained with wild-type strain, as well as for TUR1, could be related to their erratic interaction with $P$. vulgaris cv Mantequilla. $R$. etli CNPAF512 was isolated from Mesoamerican soils and has been shown to be effective with the common bean (Remans et al., 2008b), but it may not be as efficient at promoting nodule formation and nodule biomass for Andean cultivars. Several studies have focused on the lack of response of wild-type strains in common beans. Mostasso et al. (2002) and Hungría et al. (2003) demonstrated the low activity of the reference strain as CIAT899 when used to inoculate $P$. vulgaris.

Despite the high diversity of morphological, genetic and nodulation parameters, nitrogen fixation was rather homogenous for most of the treatments assessed (Figure 2). The native strains, including uncultured Rhizobium sp. SOS4, $R$. tropici VP2, R. leguminosarum bv. viciae Z3, $R$. leguminosarum bv. viciae COL6, $R$. mesoamericanum NAM1 and $R$. etli PIN1, yielded the highest shoot $\mathrm{N}$ content.

Results obtained using COL6 and NAM1 were expected for $\mathrm{N}$ fixation, due to the performance observed for the nodulation parameters. Voisin et al., (2003) and Yadegari and Rahmani (2010) reported that with respect to the amount of $\mathrm{N}_{2}$ symbiotically fixed by leguminous plants, such as common beans inoculated with efficient Rhizobium strains, increased $\mathrm{N}$ fixation is strongly correlated with the number of nodules and nodular biomass. However, the results displayed with the inoculation of Rhizobium sp. SOS4, which did not induce higher nodule numbers and had one of the lower nodule biomass production values, is rather interesting. The results suggest that this strain had a negative interaction with the tested bean genotype for nodulation parameters, but the nodules formed can fix enough $\mathrm{N}$ to contribute to plant nutrition. Surprisingly, 11 isolated strains did not affect the $\mathrm{N}$ content in plants, having no significant difference with the control, demonstrating that only some Rhizobium-Mantequilla interactions can produce an efficient symbiosis. Similar results were observed by Cardoso et al. (2017), who identified several native Rhizobium strains that stimulated nodule dry weight in common beans, but 
most of them were unable to produce a positive effect on total $\mathrm{N}$ content. In this study, more than half of the strains fixed less $\mathrm{N}$ than the control treatment without inoculation, and approximately $20 \%$ of isolates showed a symbiotic efficiency similar to or better than the best Rhizobium reference strain CIAT899.
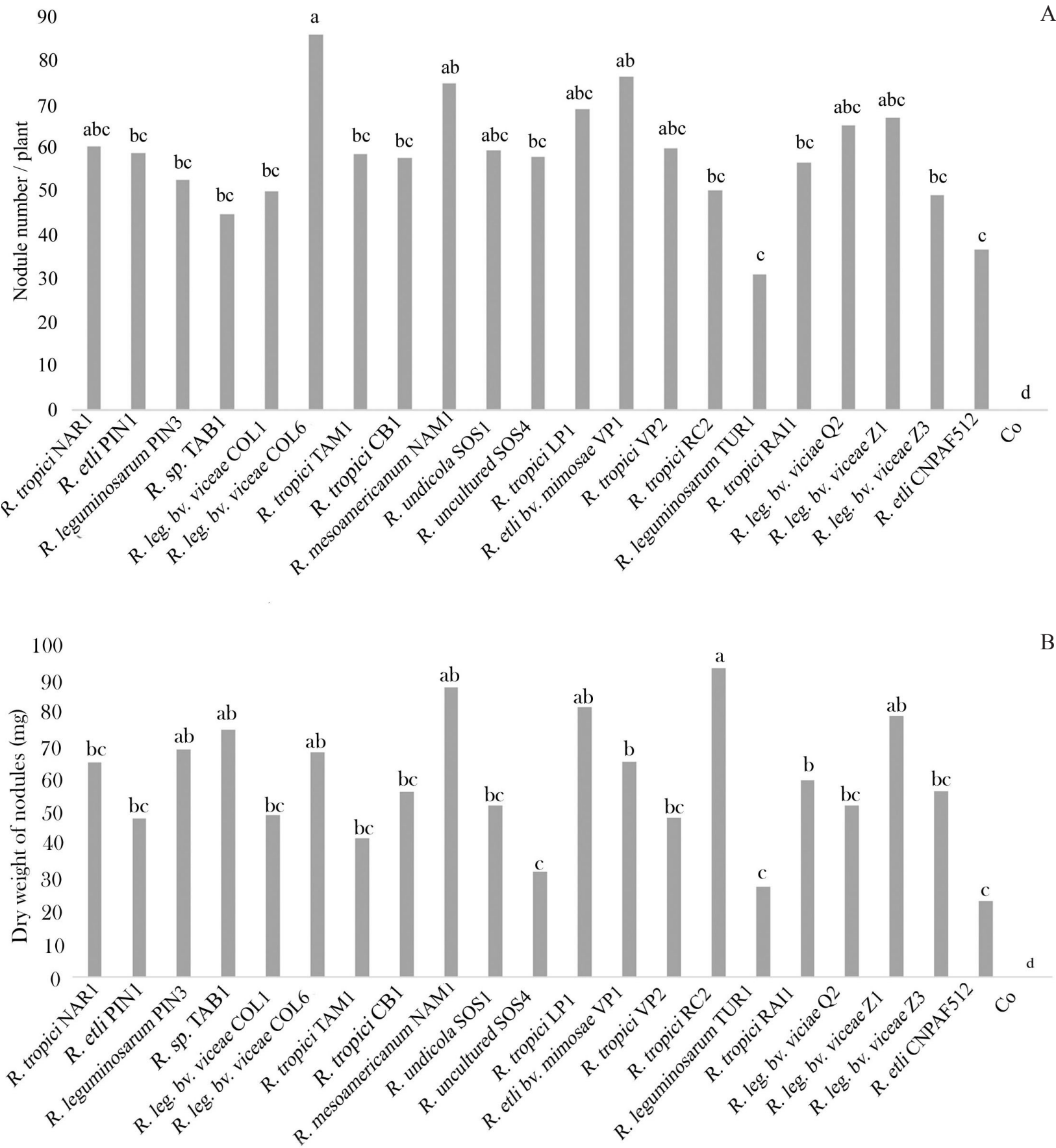

Figure 1: Nodule number (A) and nodular biomass (B) by strain. Plants were inoculated with the isolates showed in each column. Co: plant no inoculated. Letters on bars indicate significant differences between the mean ranges according to the ANOVA and Tukey's test for $\mathrm{p} \leq 0.05, \mathrm{n}=10$. 


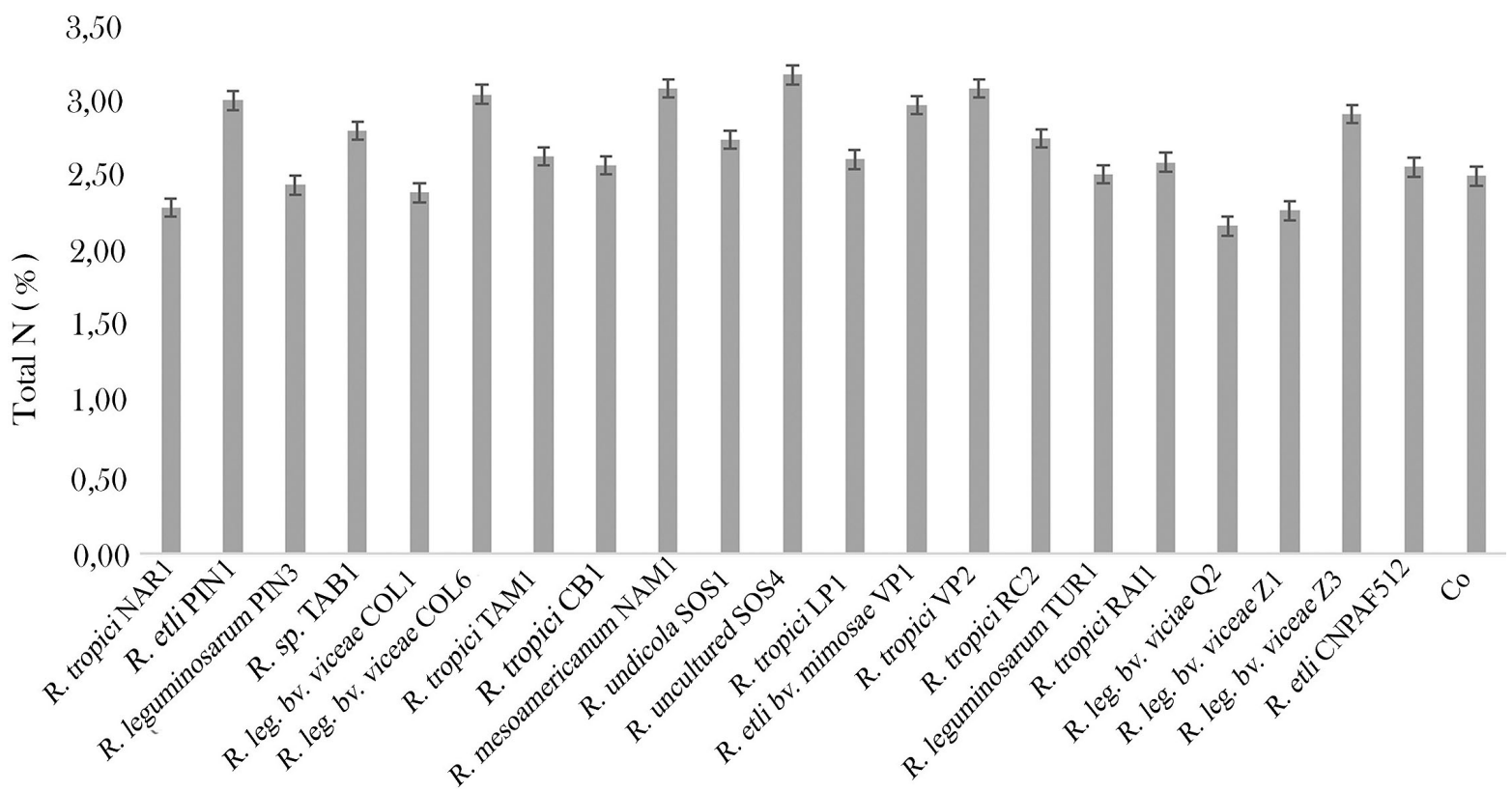

Figure 2: Nitrogen fixation by Phaseolus vulgaris cv. Mantequilla inoculated with Rhizobium strains and noninoculated treatments. For the analysis, the shoot from each treatment was dried and processed by the Kjeldahl method. Letters on bars indicate significant differences between the mean ranges according to the ANOVA and Tukey's test for $p \leq 0.05, n=10$. In addition to the ability of bacteria to survive under different salt concentrations, $\mathrm{pH}$ values or temperatures, the ability to produce plant growth promoting substance are important characteristics that contribute to a proper interaction with host plants and helps increase plant growth parameters and yields. In the study, the quantification of IAA production by bacteria showed that all isolates, and wild-type strain $R$. etli CNAP512 as positive control, had the ability to release the phytohormone (Figure 3 ).

It should be noted that the amount of IAA produced by most of the isolated strains was high compared with other studies, such as those conducted by Asghar et al. (2002) and Waheed et al. (2014), where the average concentrations of IAA produced by Rhizobium strains reached 10.5 and $14.25 \mu \mathrm{g} \mathrm{ml}^{-1}$, respectively. In this study, we obtained an average of IAA production of $138 \mu \mathrm{g} \mathrm{ml}^{-1}$ and the lowest values ranged between 16 and $22 \mu \mathrm{g} \mathrm{ml}^{-1}$ (strains CB1, VP1, RAI1 and TAB1).

The statistical analysis revealed that several strains, including $R$. leguminosarum bv. viciae COL6, $R$. mesoamericanum NAM1, $R$. tropici $\mathrm{RC} 2, R$. etli CNPAF512, $R$. leguminosarum bv. viceae COL1 and $R$. etli PIN1 produced the highest amounts of IAA. Interestingly strains such as $R$. leguminosarum bv. viciae COL6, $R$. mesoamericanum NAM1 also produced high amounts of IAA.

Most Rhizobium species have been shown to produce IAA via different pathways (Theunis et al., 2004), and many studies indicate that changes in the auxin balance in the host plant are a prerequisite for nodule organogenesis (Mathesius et al., 1998). Although the exact role of IAA in the different stages of the Rhizobium/plant symbiosis remains unclear (Janczarek et al., 2014), auxins are involved in multiple processes, including cell division, differentiation and vascular bundle formation (Theunis et al., 2004). These three events are also necessary for nodule formation. Thus, it seems likely that auxins play a role in nodulation, as well as in the regulation of root system development in plants (Crespi; Frugier, 2009). Therefore, the production of IAA by Rhizobium species isolated from southern Ecuador, and in particular the isolates $R$. leguminosarum bv. viciae COL6, $R$. mesoamericanum NAM1 and $R$. tropici $\mathrm{RC} 2$ strains, indicate that their plant/growth promoting activity may include not only symbiotic nitrogen fixation but also an adequate ability to produce phytohormones that could be related to the increase in nodulation after inoculation with the common bean cv. Mantequilla. 
160

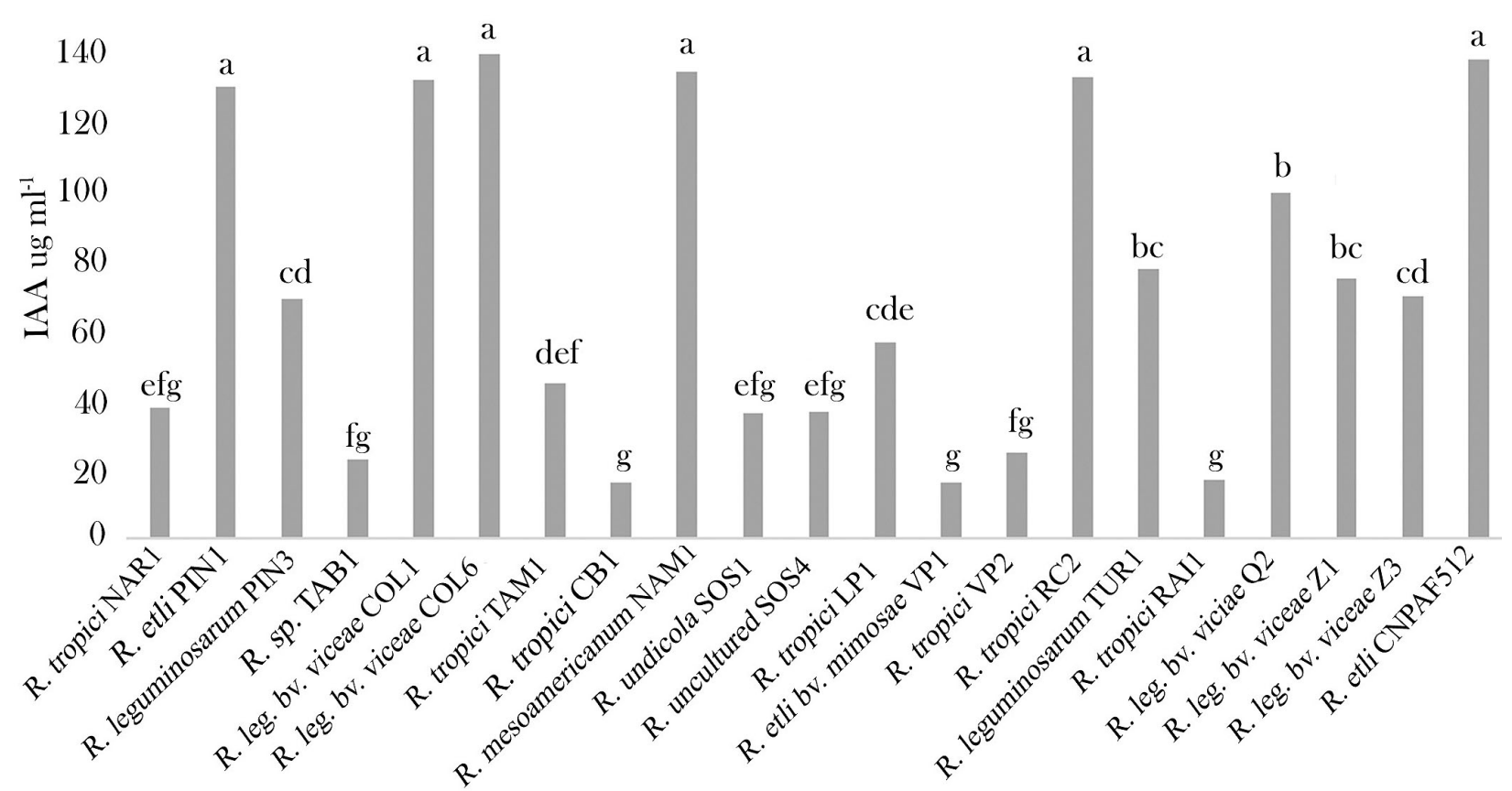

Figure 3: Quantification of IAA production by bacteria. Letters on bars indicate significant differences between the mean ranges according to the ANOVA and Tukey test for $p \leq 0.05, n=3$.

Taking into account the holistic results of this research, the strain $R$. leguminosarum bv. viciae COL6 is a promising candidate for use in inoculants (biofertilizers) and for future studies under greenhouse and field conditions to further study the Rhizobium-legume symbiosis and the genotypic diversity among Rhizobium species and local bean cultivars.

\section{CONCLUSIONS}

This study presented the first report of the isolation, genetic identification and phenotypic diversity of Rhizobium species associated with Phaseolus vulgaris cv. Mantequilla in southern Ecuador. Several strains ( $R$. leguminosarum bv. viciae COL6, $R$. tropici $\mathrm{CB} 1$ and $R$. undicola SOS1) exhibited an ability to grow at different $\mathrm{pH}$ values, salinity conditions, temperatures and altitudes (from 800 to 2691 m.o.s.l). In fact, only these strains were able to grow under all the evaluated parameters, while the molecular analysis identified a high diversity of Rhizobium species (R. tropici, R. etli, $R$. leguminosarum bv. viciae, $R$. mesoamericanum, $R$. undicola, $R$. etli bv. mimosae $R$. uncultured and $R$. sp.) at the sampling sites. However, the predominance of $R$. tropici was remarkable. The presence of a non-cultured
Rhizobium isolated suggest the needs to perform more molecular analyses to elucidate the potential presence of novel Rhizobium species in the south of Ecuador. The results under greenhouse conditions showed the promiscuity of a local Phaseolus vulgaris cultivar to form nodules with several species of Rhizobium. The stimulation of nodulation by Rhizobium species and the legume P. vulgaris cv. Mantequilla was evident. However, all the tested strains produced different results in terms of numbers of nodules, nodular dry biomass and percentage nitrogen fixation, with $R$. leguminosarum bv. viciae COL6, $R$. mesoamericanum NAM1 producing the most significant results for most of the parameters analyzed. IAA-producing Rhizobium species, in particular by Rhizobium leguminosarum COL6 and $R$. mesoamericanum NAM1 indicate that the promoter activity of plant/growth may include not only symbiotic nitrogen fixation but also a high production of phytohormone. These results suggest that these promising strains could to be used as biofertilizers for field applications. However, more trials need to be conducted to determine the effectiveness of the stimulation on nodulation, biomass, and nitrogen fixation related to yields of several beans cultivars. 


\section{ACKNOWLEDGMENTS}

The authors acknowledge the contribution of Prometeo Project from Secretaría Nacional de Eduación Superior, Ciencia, Tecnología e Innovación (SENESCYTEcuador) and the National University of Loja for external and internal founding respectively. Also to the technical staff of the Center for Microbial and Plant Genetics of Catholic University of Leuven (Belgium) for the support for sequencing reactions.

\section{REFERENCES}

AGUILAR, O. M.; RIVA, O.; PELTZER, E. Analysis of Rhizobium etli and of its symbiosis with wild Phaseolus vulgaris supports coevolution in Ann Microbiol centers of host diversification. Proceedings of the National Academy, 101(37):1354813553, 2004.

ANDRADE, D. S.; MURPHY, P. J.; GILLER, K. J. The diversity of Phaseolus-nodulating rhizobial populations is altered by liming of acid soils planted with Phaseolus vulgaris L. in Brazil. Applied and Environmental Microbiology, 68:4025-4034, 2002.

ASGHAR, H. N. et al. Relationship between in vitro production of auxins by rhizobacteria and their growth promoting activities in Brassica juncea L. Biology and Fertility Soil, 35:231-237, 2002.

BAGINSKY, C. et al. Genetic diversity of Rhizobium from nodulating beans grown in a variety of Mediterranean climate soils of Chile. Archives of Microbiology, 197(3):419429, 2015.

BHATTARAl, N. et al. Effect of Mycorrhiza and Rhizobium on Phaseolus vulgaris L. Scientific World, 9(9):66-69, 2011.

BÉCQUER, J.; PRÉVOST, D.; PRIETO, A. Caracterización fisiológica bioquímica de cepas de rizobios, aislados en leguminosas forrajeras. Biología, 14:123-130, 2000.

$B E E B E, S$. et al. Diversity and origin of Andean landraces of common bean. Crop Science, 41:854-862, 2001.

BERNAL, G.; GRAHAM, P. H. Diversity in the rhizobia associated with Phaseolus vulgaris L. in Ecuador, and comparisons with Mexican bean rhizobia. Canadian Journal of Microbiology, 47:526-534, 2001.

CARDOSO, A. A., et al. Characterization of rhizobia isolates obtained from nodules of wild genotypes of common bean. Brazilian Journal of Microbiology, 48(1):43-50. 2017.

CLERMONT, D. et al. Microbacterium binotii sp. nov., isolated from human blood. International Journal of Systematic and Evolutionary Microbiology, 59(5):1016-1022, 2009.
CRESPI, M.; FRUGIER, F. De novo organ formation from differentiated cells: Root nodule organogenesis. Science Signaling, 1:1-8, 2009.

DEBOUCK, D. G. et al. Genetic diversity and ecological distribution of Phaseolus vulgaris (Fabaceae) in northwestern South America. Economic Botany, 47(4):408-423, 1993.

ELBANNA, K.; ELBADRY, M.; GAMAL-ELDIN, H. Genotypic and phenotypic characterization of rhizobia that nodulate snap bean (Phaseolus vulgaris L.) in Egyptian soils. Systematic and Applied Microbiology, 32(7):522-530, 2009.

FUENTES, J. B. et al. Symbiotic root nodule bacteria isolated from yam bean (Pachyrhizus erosus). The Journal of General and Applied Microbiology, 48:181-191, 2002.

GLICKMANN, E.; DESSAUX, Y. A critical examination of the specificity of the Salkowski Reagent for indolic compounds produced by phytopathogenic bacteria. Applied and Environmental Microbiology, 61:793-796, 1995.

GRANDA MORA, K. I. et al. Respuesta de Phaseolus vulgaris cv. Mantequilla a la inoculación de cepas de Rhizobium nativas de Ecuador en casas de cultivo. Centro Agrícola, 43:49-56. 2016.

HUNGRÍA, M. et al. Benefits of inoculation of the common bean (Phaseolus vulgaris) crop with efficient and competitive Rhizobium tropici strains. Biology and Fertility of Soils, 39:88-93, 2003.

JANCZAREK, M. et al. Signal molecules and cell-surface components involved in early stages of the legume-rhizobium interactions, Applied Soil Ecology, 85:94-113, 2014

JUNIER, P. et al. Genetic diversity of Rhizobium present in nodules of Phaseolus vulgaris L. cultivated in two soils of the central region in Chile. Applied Soil Ecology, 80:60-66, 2014.

KASCHUK, G. et al. Genetic diversity of rhizobia associated with common bean (Phaseolus vulgaris L.) grown under no-tillage and conventional systems in Southern Brazil. Applied Soil Ecology, 32:210-220, 2006.

KAWAKA, F. et al. Symbiotic efficiency of native rhizobia nodulating common bean (Phaseolus vulgaris L.) in soils of Western Kenya. International Scholarly Research Notices, 2014:8, 2014.

KULKARNI, S.; NAUTIYAL, C. S. Effects of salt and pH stress on temperature-tolerant Rhizobium sp. NBRI330 nodulating Prosopis juliflora. Current Microbiology, 40: 221-226, 2000.

KUYKENDALL, L. D.; FAMILY, I. The Rhizobiaceae. In: BREENER, D. J. et al. Bergey's Manual of Systematic Bacterioly. New York: Springer, 2005. v. 2, p.324-361. 
LÓPEZ-GUERRERO, M. G. et al. Rhizobium etli taxonomy revised with novel genomic data and analyses. Systematic and Applied Microbiology, 35:353-358, 2012.

MARQUINA, M.; GONZÁLEZ, N. G.; CASTRO, Y. Caracterización fenotípica y genotípica de doce rizobios aislados de diversas regiones geográficas de Venezuela. International Journal of Tropical Biology, 59:1017-1036, 2011.

MARTÍNEZ-ROMERO, E. Diversity of Rhizobium-Phaseolus vulgaris symbiosis: Overview and perspectives. Plant and Soil, 252:11-23, 2003.

MATHESIUS, U. et al. Auxin transport inhibition precedes root nodule formation in white clover roots and is regulated by flavonoids and derivatives of chitin oligosaccharides. The Plant Journal, 14:23-34, 1998.

MEHBOOB, I. et al. Potential of rhizosphere bacteria for improving Rhizobium-legume symbiosis, Plant Microbe Symbiosis: Fundamentals and Advances, 12:310-311, 2013.

MICHIELS, J. et al. Phaseolus vulgaris is a non-selective host for nodulation. FEMS Microbiology Ecology, 26:193-205, 1998.

MIRANSARI, M. et al. Improving soybean (Glycine max L.) $\mathrm{N}_{2}$ fixation under stress. Journal of Plant Growth Regulation, 32(4):909-921, 2013.

MOSTASSO, L. et al. Selection of bean (Phaseolus vulgaris L.) rhizobial strains for the Brazilian Cerrados. Field Crops Research, 73:121-132, 2002.

NAVEED, M. et al. Perspectives of rhizobial inoculation for sustainable crop production. In: ARORA, N. K. Plant Microbes Symbiosis: Applied Facets. Springer India, 2015, p.209-239.

OLIVEIRA, J. P. et al. Genetic diversity of rhizobia in a Brazilian oxisol nodulating Mesoamerican and Andean genotypes of common bean (Phaseolus vulgaris L.). World Journal of Microbiology and Biotechnology, 27:643-650, 2011.

ORMENO-ORILLO, E.; MARTINEZ-ROMERO, E. Phenotypic tests in Rhizobium species description: An opinion and (a sympatric speciation) hypothesis. Systematic and Applied Microbiology, 36:145-147, 2013

PAGE, A. L.; MILLER, R. H.; KEENEY, D. R. Methods of Soil Analysis, Part II. Chemical and Microbiological Properties. Agronomy No 9. American Society of Agronomy - Soil Science Society of America, Madison, WI, USA, 1982. 821p.

PEARSON, W. R. Rapid and sensitive sequence comparison with FASTP and FASTA. Methods in Enzymology, 183:6398, 1990.
RAHMANI, H. A. et al. Genetic diversity and symbiotic effectiveness of rhizobia isolated from root nodules of Phaseolus vulgaris L. grown in soils of Iran. Applied Soil Ecology, 48:287-293, 2011.

REMANS, R. et al. Effects of plant growth-promoting rhizobacteria on nodulation of Phaseolus vulgaris $\mathrm{L}$. are dependent on plant P nutrition. In: BAKKER, P. A. H. M. et al. New perspectives and approaches in plant growth-promoting Rhizobacteria research. Springer, Netherlands, 2007, p.341-351.

REMANS, R. et al. Effect of Rhizobium-Azospirillum coinoculation on nitrogen fixation and yield of two contrasting Phaseolus vulgaris L. genotypes cultivated across different environments in Cuba. Plant Soil, 312:25-37, 2008a.

REMANS, R. et al. Physiological and genetic analysis of root responsiveness to auxin-producing plant growth-promoting bacteria in common bean (Phaseolus vulgaris L.). Plant Soil, 302:149-161, 2008b.

RIBEIRO, R. A. et al. Novel Rhizobium lineages isolated from root nodules of the common bean (Phaseolus vulgaris L.) in Andean and Mesoamerican areas. Research in Microbiology, 164:740-748, 2013.

RIBEIRO, R. A. et al. Rhizobium ecuadorense sp. nov., an indigenous $\mathrm{N}_{2}$-fixing symbiont of the Ecuadorian common bean (Phaseolus vulgaris L.) genetic pool. International Journal of Systematic and Evolutionary Microbiology, 65:3162-3169, 2015.

RODIÑO, P. et al. Co-evolution and migration of bean and Rhizobia in Europe. In: LICHTFOUSE, E. Organic Farming, Climate Change and Soil Science. Springer, Netherlands, 2010, p.171-188.

SÁNCHEZ, A. C. et al. Effects of co-inoculation of native Rhizobium and Pseudomonas strains on growth parameters and yield of two contrasting Phaseolus vulgaris L. genotypes under Cuban soil conditions. European Journal of Soil Biology, 62:105-112, 2014

SHAMSELDIN, A.; WERNER, D. High salt and high pH tolerance of new isolated Rhizobium etli strains from Egyptian soils. Current Microbiology, 50:11-16, 2005.

SOMASEGARAN, P.; HOBEN, H. Handbook for Rhizobia. Springer Laboratory. New York, US, 1994, p.15.

THEUNIS, M. Flavonoids, NodD1, NodD2, and Nod-Box NB15 modulate expression of the $y 4 w E F G$ locus that is required for indole-3-acetic acid synthesis in Rhizobium sp. strain NGR234. Molecular Plant-Microbe Interactions, 17:11531161, 2004. 
VINCENT, J. M. A Manual for the practical study of rootnodule bacteria, Published for the International Biological Programme by Blackwell Scientific, 1970. 164p.

VLASSAK, K. M. et al. The Rhizobium sp. BR816 nodO Gene Can Function as a Determinant for Nodulation of Leucaena leucocephala, Phaseolus vulgaris, and Trifolium repens by a Diversity of Rhizobium spp. Molecular Plant-Microbe Interaction, 11:383-392, 1998.

VOISIN, A. S. et al. Root and nodule growth in Pisum sativum L. in relation to photosynthesis: Analysis using 13C-labelling. Annals of Botany, 92(4):557-563, 2003.

WAHEED, A. et al. Isolation and biochemical characterization of Rhizobium from pea crop at Swabi. International Journal of Biosciences, 4(8):231-240, 2014.

WEI, G. H.et al. Phenotypic and genetic diversity of rhizobia isolated from nodules of the legume genera Astragalus, Lespedeza and Hedysarum in northwestern China. Microbiological Research, 163:651-662, 2008.
YADEGARI, M.; RAHMANI, H. A. Evaluation of bean (Phaseolus vulgaris) seeds' inoculation with Rhizobium phaseoli and plant growth promoting rhizobacteria (PGPR) on yield and yield components. African Journal of Agricultural Research, 5(9):792-799, 2010.

YAMAL, G. et al. An Insight into the legume-Rhizobium interaction. In: HAKEEN, K. R.; AKHTAR, M. S. Plant, Soil and Microbes. Springer, Netherlands, 2016, p.359-384.

ZACCARDELLI, M.; PENTAGELO, A.; TRIPODI, P. Characterization of bean (Phaseolus vulgaris L.) ecotype "Fagiolo occhio nero di Oliveto Citra" using agronomic, biochemical and molecular approaches. Pakistan Journal of Biological Sciences, 16:901-910, 2013.

ZAHRAN, H. H. Rhizobium-legume symbiosis and nitrogen fixation under severe conditions in an arid climate. Microbiology and Molecular Biology Reviews, 63:969989, 1999.

ZHANG, L. et al. Rhizobium smilacinae sp. nov., an endophytic bacterium isolated from the leaf of Smilacina japonica. Antonie van Leeuwenhoek, 106:715-723, 2014. 